\title{
THE POLITICAL AND ECONOMIC RESULTS OF NOVEMBER 2013
}

\author{
S.Zhavoronkov
}

The top news story of November was the indirect polemical dispute between Vladimir Putin and Dmitry Medvedev, centered on the RF Investigative Committee's attempt to restore at least one of its previous established powers - the right of investigators to open tax fraud cases without a request from the tax authorities. So far, Putin has promised to take into account the business community's views on that matter. However, much depends on whether or not both society and businessmen are able to be outspoken on that matter, because experience has shown that the authorities seldom implement their agreements concluded behind the scenes. Also, November saw a steady rise in anxiety over the numerous challenges that Russia's financial system is faced with. Thus, a lot of worry was caused by the new losses suffered by Vneshekonombank (which is forced to increasingly abandon its role of a development institution, and to become instead a source of politically-motivated irretrievable loans designed to finance gigantic and wasteful vanity projects), the cancellation of the license of Master Bank, one of Russia's top 100 banks, etc.

November saw a relatively fascinating turn of events in ex-Defense Minister Anatoly Serdyukov's saga, when a criminal case was at long last opened against him. Serdyukov was charged with abuse of power - a somewhat minor offence, bearing in mind the torrent of recrimination poured on him for almost a year on TV channels. The case in point was Serdiukov's order to build a road to a private holiday residence belonging to his acquaintances at the expense of the RF Ministry of Defense. Having kept silence throughout the year, Serdyukov and his allies immediately counterattacked: Serdyukov was demonstratively appointed head of a relatively small enterprise, Rostechnologies (rumors of his forthcoming appointment to this post had been circulating for almost a year; when this decision was finally announced it came as no surprise to anyone, bearing in mind that Serdyukov and Rostechnologies Director General Sergei Chemezov had always been on excellent terms). At the same time, Serdiukov's close associate Yevgenia Vasilyeva, former head of the Ministry of Defense property department and a former senior official of Oboronservice, charged with much graver offences than Serdyukov, issued a number of statements insisting on her innocence, rather convincingly. Vasilyeva pointed out that investigators had simply 'invented' the 'true' market value of the surplus Ministry of Defense property sold off by her, in order to charge her with selling it at prices below its market value. She stated that most of the auctions conducted by her had failed because of absence of buyers - that is, because the bidding prices had been set too high. She insisted that witnesses in her case had been intimidated into testifying falsely against her. And she affirmed that her elite real estate had been bought by her father, a wealthy businessman who had never had any connection with the Ministry of Defense. Although Vasilyeva's statement about the 'true value' is fairly disputable, as regards the other two charges the prosecution has indeed presented a weak case. The tug of war between Serdyukov's adversaries and supporters vying for influence over Vladimir Putin makes the situation precariously balanced, which is highly detrimental to the reputation of the regime: it should be borne in mind that the authorities themselves have focused public attention on the issue of corruption in high places, while at the same time failing to understand whether or not the facts of corruption actually took place, and whether or not such deeds ought be punished, and if the answer is yes - what should the specific punishment be for one or other instance of corruption.

In November 2013, the RF State Duma unanimously passed the first reading of a draft law designed to make it illegal for federal officials to buy cars worth more than $\mathrm{Rb} 3 \mathrm{~m}$. Formally, the draft law had been introduced into the State Duma by a United Russia MP. Thus, the authorities partially succumbed to the Opposition's long-standing demand that the price of limousines for officials should be capped at Rb $1.5 \mathrm{~m}$ (Russian opposition leader Aleksey Navalny had collected 100 thousand verifiable signatures on the Internet in support of that demand). This decision can only be welcomed, although it is regrettable that it took so long for the authorities to make it. However, it should be noted that the first reading version of the draft law contains a number of legal loopholes.

Vladimir Putin checked Sochi's readiness for the Winter Olympic Games (this ceremony took place in late November under pouring rain, which came as a reminder of the climate risks faced by winter sports in 
the subtropical climate of Sochi). Problems continued to crop up in the financial field: Vneshekonombank announced that it had been forced to form reserves, in the amount of $\mathrm{Rb} 215.3 \mathrm{bn}$, for possible losses on loans issued to VEB borrowers. In the likely event that these borrowers default on their loans, their debts, according to Russia's existing legislation, will have to be repaid directly from the federal budget. This explains the government's recent decision to 'improve the situation' in the market of non-state pension funds - that is, to liquidate, for one year, the cumulative component of the labor pension. However, according to experts, the actual volume of bad credits is two to three times larger than the cumulative pension cost for one year: the owners do not need the sport venues and other infrastructure objects built for the Olympics because the money spent on them will never be recovered - the initial cost estimates were hugely exceeded, which means that the credit takers, in the first place, had never intended to pay back the loans issued to them for purely political reasons. They had never had any doubt that the credits would be written off by VEB, thus yielding them the greatest profit.

On 20 November 2013, the Central Bank of Russia revoked the license of Master Bank, citing its failure to abide by Russian legislation on money laundering and its 'large-scale suspicious operations'. Central Bank officials also said that there was also a 2 billion ruble hole in Master Bank's balance sheet generated by loans made to companies affiliated to the bank's owners. It turned out that Russia's Deposit Insurance Agency's liability to Master Bank depositors amounted to $\mathrm{Rb} 30 \mathrm{bn}$, or by $\mathrm{Rb} 10 \mathrm{bn}$ more than to the depositors of the recently declared bankrupt Pushkino Bank. It should be noted, however, that Pushkino Bank's license was revoked after the bank had stopped making payments. The situation of Master Bank was quite different, and its managers - who have not had any criminal charges filed against them so far - hinted that the matter at issue was the struggle over the re-division of the market.

The revocation of Master Bank's license created a panic in the market: experts, public relations gurus and other 'specialists' rushed to compile their lists of banks whose licenses would certainly be revoked 'tomorrow'. The panic was additionally fuelled by the incautious statement of Central Bank Head Elvira Nabiullina that Master Bank would not be the last bank to lose its license. Her remark was understood by the depositors not as meaning that 'Master Bank will not be the last crooked bank to be punished by the regulator', but that 'Master Bank will not be the last very large bank to collapse'. With Master Bank's primary documentation being unavailable, it is hard to say who is right in this matter: the bank or the regulator. However, one thing is certainly clear: it is absolutely unacceptable that currently bank clients are deprived of any information on the alarming orders and directions, including warnings, restrictions on acceptance of deposits and on creation of reserves, which are sent to their bank by the regulator, and that the banks are not obliged to publicly comment on such alarming signals. Although the desired information transparency is not a universal panacea, it is strange that Russia's financial authorities usually explain the lack of this transparency by the old cliché that the banking sector bears responsibility for the economy as a whole, which means that the clients themselves (that is, economic agents) and the real economy (not the one defined in private law systems) will be informed on one or other bank's failures only post factum, after the bank is already 'dead', while during its life time, the regulator continues to publish that bank's official reports and nothing else. So, what was the point in vesting the RF Central Bank with dictatorial powers over Russia's banks? As far as the banking sector is concerned, the $C B$ combines the functions of a lawmaker, a law enforcer and a service provider (by issuing instructions to the banking sector, by overseeing compliance with these instructions, and by granting credits to banks).

November saw a hot indirect dispute, without any mention of the names of the parties involved, between Vladimir Putin and Dmitry Medvedev. The bone of contention was the draft law designed to eliminate the current procedure for initiating criminal proceedings for tax-related offences, unexpectedly introduced into parliament by Putin. The existing procedure was introduced several years ago as one of the government's measures aiming at eradication of 'tax terrorism'. Its introduction put an end to the RF Ministry of Internal Affair's right to unilaterally initiate criminal proceedings for tax-related offences. From then onwards, it was able to do so only in tandem with the RF Tax Service (that is, only after obtaining permission from the taxmen - people usually professionally well-trained enough to see whether or not a tax-related offence has actually been committed). The reform has proved successful, as shown by the fact that the number of tax-related criminal cases has dropped six-fold because the costs of opening such cases have shot up - for a criminal case aimed at the seizure of someone's property to be opened, the raider must now control two administrative units instead of one. In this respect, Putin's legal initiative is a counterreform. However, it should be admitted that, in any case, the compact Investigative Committee - which will be granted the right to open criminal cases alone, without the consent of the Tax Service, once the draft law becomes law - will become less dangerous to Rus- 
sian business than the giant Ministry of Internal Affairs. The current version of the draft law has already been criticized by Russia's business associations and even by a number of top officials, including Dmitry Medvedev, who - maybe for the first time since 2008 - has recalled his responsibility for that glorious reform. In response, Putin advised the dissident officials to quit their jobs and join the ranks of the experts' community. The mavericks promptly put their tails between their legs and meekly went back to their normal duties. As far as the business community's objections were concerned, Putin suggested discussing the draft law with businessmen. Bearing in mind that the draft law will inevitably become law, the business community is keenly interested that the Ministry of Internal Affairs should indeed restore its previous established powers. Unfortunately, there are some signs that the Interior Ministry and its head, Vladimir Kolokoltsev, are intensifying their efforts to reclaim their former prerogatives.

The possible future course of events in Russia can be illustrated by the following example. In November, the RF State Duma hastily passed a constitutional law whereby the Supreme Arbitration Court (SAC) was to be abolished. The reason for this legislative decision was simple - it was necessary to carry out the re-certification of the judges of Russia's two supreme courts without reducing their numbers. The judges' community as a whole abstained from public protests. As a result, Russia's judges are now forced to deal with the following amazing situation: all judges of two supreme courts will be re-examined by certain collegiums, mainly to be composed of judges of the Russian Federation's subjects. Such a collegium can be rightly called a qualification commission turned upside down! It should be added that the principle of the irremovability of judges has never been followed to the hilt in contemporary Russia, where the judges' community, being at the beck and call of the executive authorities, can arbitrarily remove from office any judge. Now this principle is openly ignored.
But at the same time, we should not overestimate the merits of Russian supreme courts, even those of the Supreme Arbitration Court. It is common knowledge that the SAC has always upheld even the most controversial rulings passed by Russian courts of justice (for example, the outrageous court decisions that Telenor should be fined $\$ 1 \mathrm{bn}$ - reputedly to cover the 'losses' suffered by the owner of a tiny block of shares in Vympelkom as a result of Telenor's actions in Ukraine ( in order to have that shareholder's claim withdrawn, Telenor was forced to tap diplomatic channels).

There happened yet another deadly aviation disaster, when an old airplane owned by the quasi-stateowned company Tatarstan crashed and burst into flames while attempting to land at Kazan International Airport, killing everyone on board, including the son of the President of Tatarstan. The air crash immediately triggered a hot debate as to whether or not this one and other similar disasters had been caused by the venerable age of Russia's passenger air fleet (each of the perished planes was 20-plus-yearold), the scandalously low qualification of the pilots (for example, the pilots of the airliner crashed at Kazan had been trained hastily and thus inadequately), or by poor maintenance and repair. Apparently the disaster was caused by a combination of all those factors. In any case, society is well aware of the fact that the air crash rate in Russia is four times the world average (which included many backward countries). Although Russians travel by air much less frequently than citizens of some other countries, aviation disasters occur in Russia almost every year. The main culprit is the awful state of Russia's aircraft industry, comparable with that of her automotive industry ten years ago. Unfortunately, the Russian authorities are still refusing to acknowledge this fact. Instead, they continue to put the blame on pilot errors and to ignore the host of other possible reasons for aviation accidents. 